\title{
An Emperical Investigation of the Effectiveness of Sales Promotion in Maltina and Malta Guinness Sales Promotion Strategies
}

Christiana Shade Ade-Johnson*

Department of Mass Communication, Rufus Giwa Polytechnic, Owo, Ondo State, Nigeria

\begin{abstract}
Modern business relies by and large to a great extent on sales promotion. In introducing and retaining a product or service, proponents of the product and service depend on sales and marketing promotions. It is against this backdrop that this study is borne to investigate the use of sales promotion as promotional strategy in the malt market in Nigeria using two malt drinks-Maltina and Malta Guinness as samples. The study investigated the effectiveness of sales promotion in the main market unit in the beverages industry in Nigeria. With 500 respondents and two Field managers in the two major malt producers in Nigeria, the study used survey method of data gathering using questionnaire and interview guide as instruments. It found out that sales promotion is an effective promotional tool for the introduction and retaining customers' loyalty and awareness.
\end{abstract}

Keywords: Sales promotion strategies; Market share; Consumer behaviour

\section{Introduction}

As never before, the business world is facing a critical time. The $21^{\text {st }}$ century appears to be unfriendly to businesses especially the FastMoving-Consumers-Goods Industry. The economic recession facing the world as a whole brought along more hostile factors that militates against the business world. It is more critical to do and run enterprises in this age as investments in different sectors are taking more nosediving than appreciating [1]. Compounding the problem more is the tremendous demands made by the consumers taste, feelings, interests and lifestyles. With an intense drive, organizations must be attuned to the incessant changes confronting the market. These realities in the market place thrust a burden of tough responsibilities on organizations to keep understudying the fluidity of consumer behaviour and other dynamics of the market [2]. This makes the business environment more competitive for brands, than ever before. As many brands storm the market place, a large percentage of the brands also fade out of the market and even into oblivion [3]. Therefore, to survive in the turbulent market environment, it is more of evolving and deploying strategic marketing tools that could enable the brand to perform in the market place. To marketers and their organizations, this idea of brand performance in the market is all about market share. That is, brands must command larger sale in the market. In the Nigerian market environment, driving performance has made sales promotion one of the most consistently and widely used marketing tool [4].

Sales promotion essentially, has been seen as more of tactical approach than strategic engagement in marketing of brands. Predominantly, marketing practitioners and scholars believe that sales promotion cannot be engaged to build brand equity. It is basically regarded as a mere short-term technique to generate increase in sales but deficient in elevating brand image and perception $[2,5,6]$. However, recently, sales promotion is being deployed on a large scale consistently on a strategic platform. According to Kotler and Keller [7] "A decade ago, the Advertising-to-Sales promotion ratio was about 60:40. Today, in many consumer-packaged-goods companies, sales promotion accounts for $75 \%$ of combined budget (Roughly $50 \%$ is trade promotion and $25 \%$ is consumer promotion)'.

Most organizations are now conceptualizing and executing sales promotion solely to actualize their marketing objective. Sales promotion usage has been increasing immensely as a marketing tool for over a decade [4]. Questions have been raised on the dramatic turnaround in the use of sales promotion across different market climes the world over. Several factors have been identified as responsible for the rise in the deployment of sales promotion. Prominently among these factors is attributed to the surprise positive response of the organization management group to the marketing executives. Also the number of brands in the market place has increased geometrically in the last two decades accounting for intensive competitive nature of the brand markets in virtually all industries. Furthermore, the competitors have seen the needs to drive brands performance through massive use of sale promotion, essentially, when consumers have become more priceoriented. In addition, the trade networks in businesses are making more demands of deals from manufacturers. Lastly, it is becoming apparent that advertising is losing its strength in marketing plan and effort in most brands' markets [7].

Arising from the fact that the Nigerian market environment is not insulated from the grip of sales promotion in driving brand performance in the market place (from the telecommunication sector, banking and most especially to the consumer brands) the use of sale promotion has been on the increase. For example, the telecom industry with prominent players such as MTN, Globacom, Airtel and Etisalat, account for $55 \%$ of sales promotions deployment as a marketing tool. The banking industry takes the remaining percentage. It has, however, been observed that organizations in the food and beverage industry have been attributing too much to sales promotion. There is a significant rise in the use of sales promotion in the food and beverages industry to the extent that one brand management commentator remarks, "with the way marketers create and execute sales inducement and customersincentive programmes, it is becoming almost impossible to engage the

*Corresponding author: Christiana Shade, Dept of Mass Communication Rufus Giwa Polytechnic, P.M.B. 1019, Owo, Ondo State, Nigeria, Tel: 234-803473-0783; E-mail: Sunshineoasis12@gmail.com

Received May 20, 2014; Accepted July 02, 2014; Published July 09, 2014

Citation: Ade-Johnson CS (2014) An Emperical Investigation of the Effectiveness of Sales Promotion in Maltina and Malta Guinness Sales Promotion Strategies. J Mass Communicat Journalism 4: 204. doi:10.4172/2165-7912.1000204

Copyright: @ 2014 Ade-Johnson CS. This is an open-access article distributed under the terms of the Creative Commons Attribution License, which permits unrestricted use, distribution, and reproduction in any medium, provided the original author and source are credited. 
competition without the use of sales promotion in the Fast-MovingConsumers-Goods, most especially in beverages industry" [8]. The beverages industry in Nigeria is critically undergoing a marketing upheaval. To achieve the competitive edge, marketers have seen that sales promotion enable speedy return on investment in marketing. The key driver is more or less response to competitive market environment.

\section{Statement of Problem}

This study intends to ascertain the above assumption about the massive usage of sales promotion in the main market which is a market unit in the beverages industry. For some time, the two powerful players in the malt market in Nigeria; Nigeria Breweries Plc producing Maltina brand and the Guinness Plc manufacturing the Malta Guinness, have been engaging the tool of sales promotion to outdo each other in the Malta market. The sales promotion campaigns from the two organizations have not only been consistent but are really competitive, gulping immense resources.

To drive up brand performance in the market place, sales promotion has been classified; and this classification does not add to a brand value except in the area of sales. The conventional idea is that it is a short term tactics only useful to move quick sales. It is on the basis of this that experts argue that sales promotion cannot deliver on brand values on a long term pursuit. But the malt market in Nigeria is littered with sales promotion campaigns and activities primarily geared to creating a strong platform for brand building and launching marketing offensive in brand competition. This runs contrary to the conventional wisdom in brand marketing, worldwide. It is against this backdrop that this current market reality in malt market becomes a major concern of empirical investigation. The rationale for the selection of this segment is premised on the fact that malt market has been considered to be one of the prominent playgrounds for massive and incessant deployment of sales promotion.

\section{Methodology}

The study employed survey as the method of data gathering using questionnaire and interview guide as instruments. Five hundred copies of questionnaire were administered and, an interview guide was developed for the interview session to be conducted with the Field Managers of Maltina and Malta Guinness.

\section{Literature Review}

\section{Sale promotion}

Sales promotion is basically a marketing technique employed to maximize increase in sales within a period of time (M2). Kotler [6] defines sales promotion as a key ingredient in marketing campaigns consisting of a diverse collection of incentive tools, mostly short term, designed to stimulate quicker or greater purchase of particular products or services by consumers or the trade.

According to Egan [9], sales promotion is the offering of an incentive to make people act. By its very nature, it is tool 'urgency', designed to encourage buyers act immediately before it is too late. It has the function of 'acceleration' being designed to increase the volume of sales by directly influencing the decision-making process and influencing the 'speed of decision'.

Sales promotion offers buyers additional value, as an inducement to generate an immediate sale. These inducements can be targeted at customers, distributors, agents and members of the sales force. Sales promotion is traditionally referred to as below-the-line communication because unlike advertising, there are no commission payments from the media owners with this marketing communication tool. The promotional costs are borne directly by the organization initiating the activity, which in most cases is a manufacturer, producer or service provider [9].

Also, Lee cited in Egan [9] suggests that sales promotion is driven by four main factors in marketing effort. These four factors are basically the strategic premises that do trigger the use of sales promotion. $\mathrm{He}$ believes that sales promotion is used:

- as a reaction to competitor(s)

- as a form of inertial-this is what we have always done

- as a way of meeting short-term sales objectives

- as a way of meeting long term objectives

According to Shimp [10], sales promotion is any incentive used by manufacturers to induce the trade (wholesales, retailers or other channel members) or consumers to buy a brand and to encourage the sales force to aggressively sell it. Shimp believes that when such incentives are given, promotion has the power to influence the behaviour of the buyers. This knowledge alone does not make the organization embark on sales promotion. It must have a goal. Such goals may be to:

- inform

- remind

- create awareness about a new product

- increase sales

- block competitors

- combat competitors

- decongest excess stock

- neutralise or disrupt competition

- target a specific segment

- reward loyal customers

- encourage brand switching

Most marketing scholars strongly assert that these goals of sales promotion are short term oriented. However, Peattie and Peattie are of the opinion that sales promotion can be of a long term if it is valueadding. It is value-adding when unique or remarkable value is added by offering something to augment fundamental product price like the premium (gift). These have potential to add value over the longer term. On the basis of this line of thought on sales promotion, Peattie and Peattie allude to the fact that sales promotion can alter a brand perception in the market place. This becomes highly imperative as marketers have begun to deploy sales promotion not only consistently but building their brand values and perception on it as a strategic platform [11].

Dozie observation registers a sharp contrast with the conventional western marketing wisdom which established that sale promotion is not to be deployed for brand building. This idea conceives sales promotion as a mere tactical tool for maximizing increase in sales. It does not portend any good for effective performance of brand outside sales $[7,9,10]$. It can be deduced from the above marketing philosophy on sales promotion that this should be a universal marketing wisdom as regards the deployment of sales promotion. However, marketers 
in Nigeria are utilizing sales promotion in a massive and extensive manner to construct and reconstruct their brand image and perception with the intention of achieving a competitive edge in the market areas. This poses a challenge to the position of western marketing scholars who believe unreservedly that sales promotion is ineffective in brand building efforts. As a matter of fact, Corfman and Ragubir cited in Kazim and Batra [12] remark "offering sales promotion programmes to support products penetration into the market on constant basis is more likely to lower a brand evaluation of value." In Nigerian marketing context of today, this marks a departure from the globally held sales promotion

\section{Shimps principle of consumer motivation in sales promotion}

Shimps [10] provides a set of theoretical assumptions which could be a sort of cumulative observations made on the effect study of sales promotion. Shimps believes that:

- Temporary price reductions can substantially increase sales

- The greater the frequency of deals the lower the increased sales

- The frequency of the deals changes the customers' preference

- Higher market-share brands less deal elastic

- Advertised promotion increase store traffic

- Higher quality brand tend to steal sales from lower quality brands

\section{Consumer perception}

Most consumer perception research deals with perceptual interpretation. This is fundamental to issues of perceived product and service quality. Perceptual judgments begin with selective attention to perceptual stimuli in the marketing landscape. Through selective exposure and attention, consumers form basic images of brands, products, and marketing communications. They draw basic perceptual inferences about the attributes of these marketing stimuli [5]. Through learning and experience, consumers eventually form summary perceptual judgment that links the sensory stimuli to outcomes they consider probable; because consumers acquire information selectively, marketers must examine such issues as perceived quality and PCI in developing an understanding of particular consumers' perceptual judgments of particular market offerings [13].

\section{Theoretical Framework}

\section{Push strategy of sales promotion}

The push theory of sales promotion techniques supports that you promote your goods to middle-men comprising of wholesalers and retailers, who will then pass the wares along to their consumers.

A "push" promotional strategy makes use of a company's sales force and trade promotion activities to create consumer demands for a product. The producer promotes the product to the wholesales, the wholesalers promote it to the retailers and the retailers promote it to the consumers.

\section{Pull strategy of sales promotion}

The consumers are the main target of pull strategy of sales promotion. It requires a massive advertising spending to generate awareness for the sales promotion campaign. The idea is to attract the target market for massive sales within a period of time. Sales promotion using pull strategy also enables organization to reward their loyal customers.

\section{Combination of pull and push strategy}

Marketers can also combine the push and pull strategy of sales promotion to engage the realities of the market place. The blending of the two strategies is dictated by the nature of the market in which a brand exists. Marketers do study and analyze the dynamics of the market place to determine the sales promotion strategy that will be deployed at a given time.

\section{Game theory: Bertrand's model}

One model of duopoly is the strategic game in which

- the players are the firms

- the actions of each firm are the set of possible outputs (any nonnegative amount)

- the payoff of each firm is its profit.

Bertrand competition: describes interactions among firms (sellers) that set prices and their customers (buyers) that choose quantities at the prices set. It initially argued that when firms choose quantities, the equilibrium outcome involves firms pricing above marginal cost and hence the competitive price. However, Bertrand argued that if firms chose prices rather than quantities, then the competitive outcome would occur with price equal to marginal cost. The model rests on very specific assumptions. There are at least two firms producing a homogeneous (undifferentiated) product and cannot cooperate in any way. Firms compete by setting prices simultaneously and consumers want to buy everything from a firm with a lower price (since the product is homogeneous and there are no consumer search costs). If two firms charge the same price, consumers demand is split evenly between them. It is simplest to concentrate on the case of duopoly where there are just two firms, although the results hold for any number of firms greater than 1.

A crucial assumption about the technology is that both firms have the same constant unit cost of production, so that marginal and average costs are the same and equal to the competitive price. This means that as long as the price it sets is above unit cost, the firm is willing to supply any amount that is demanded (it earns profit on each unit sold). If price is equal to unit cost, then it is indifferent to how much it sells, since it earns no profit). Obviously, the firm will never want to set a price below unit cost, but if it did it would not want to sell anything since it would lose money on each unit sold.

\section{The Bertrand duopoly equilibrium}

First, if both firms set the competitive price with price equal to marginal cost (unit cost), neither firm will earn any profits. However, if one firm sets price equal to marginal cost, then if the other firm raises its price above unit cost, then it will earn nothing, since all consumers will buy from the firm still setting the competitive price (recall that it is willing to meet unlimited demand at price equals unit cost even though it earns no profit). No other price is an equilibrium. If both firms set the same price above unit cost and share the market, then each firm has an incentive to undercut the other by an arbitrarily small amount and capture the whole market and almost double its profits. So there can be no equilibrium with both firms setting the same price above marginal cost. Also, there can be no equilibrium with firms setting different prices. The firms setting the higher price will earn nothing (the lower priced firm serves all of the customers). Hence the higher priced firm 
will want to lower its price to undercut the lower-priced firm. Hence the only equilibrium in the Bertrand model occurs when both firms set price equal to unit cost (the competitive price).

Note that the Bertrand equilibrium is a weak Nash-equilibrium. The firms lose nothing by deviating from the competitive price: it is equilibrium simply because each firm can earn no more than zero profits given that the other firm sets the competitive price and is willing to meet all demand at that price.

\section{Results}

The data presented in Table 1 shows that majority of the respondents 177 (35.4\%) indicated that they like these brands based on their taste, $72(14.4 \%)$ noted that their preference for these brands stems from their low fat, while 96 (19.2\%) stated that they prefer the brands because of the low sugar and nutritious content.

Table 2 reveals that majority of the respondents (73.6\%) participated regularly in the sales promotions of these brands under study while 56 $(11.27 \%)$ of the respondents said they rarely participated in such sales promotions.

The data presented in Table 3 shows that an overwhelming majority of $60.8 \%$ were motivated by prizes given during sales promotion activities. While respondents of $112(22.4 \%)$ stated reduction in the prices of the brands as motivating force.

Table 4 further gives credence to the fact presented in Table 3 that majority of the respondents 405 (81\%) were motivated by the prizes to be won during sales promotion activities. 35 (7\%) respondent said they took five bottles because these brands give energy while $24(4.8 \%)$ of respondents were motivated by the nutrient content.

In Table 5, 128(25.6\%) respondents strongly agreed that they would still patronize these brands if there is no sales promotions, $200(40 \%)$ also agreed to patronize Maltina and Malta Guinness regardless of promotion. On the other hand, 150 (30\%) gave contrary opinion while

\begin{tabular}{|l|c|c|c|}
\hline Responses & Frequency & Percentage & Cumulative percentage \\
\hline Cools my mind & 40 & 8 & 8 \\
\hline Cools my taste & 32 & 6.4 & 14.4 \\
\hline Low fat & 72 & 14.4 & 28.8 \\
\hline It's much better & 32 & 6.4 & 32.5 \\
\hline Low sugar & 48 & 9.6 & 44.8 \\
\hline Soothes me & 16 & 3.2 & 48 \\
\hline Nutritious & 48 & 9.6 & 57.6 \\
\hline Malting taste & 26 & 5.2 & 62.8 \\
\hline It tastes cool & 15 & 3 & 65.8 \\
\hline Nice taste & 136 & 27.2 & 93 \\
\hline Natural taste & 15 & 3 & 96 \\
\hline Cost & 8 & 1.6 & 97.6 \\
\hline Brand & 16 & 3.2 & 100.8 \\
\hline Total & $\mathbf{5 0 0}$ & $\mathbf{1 0 0}$ & \\
\hline
\end{tabular}

Table 1: Showing responses on reasons for patronage.

\begin{tabular}{|l|c|c|c|}
\hline Options & Frequency & Percentage & Cumulative percentage \\
\hline Always & 264 & 52.8 & 52.8 \\
\hline Most times & 104 & 20.8 & 73.6 \\
\hline Seldom & 56 & 11.2 & 84.8 \\
\hline Once & 56 & 11.2 & 96 \\
\hline No response & 20 & 4 & 100 \\
\hline Total & $\mathbf{5 0 0}$ & $\mathbf{1 0 0}$ & \\
\hline
\end{tabular}

Table 2: Showing the frequency of respondents' participation in the promotion.

\begin{tabular}{|l|c|c|c|}
\hline Response & Frequency & Percentage & Cumulative percentage \\
\hline Prizes & 304 & 60.8 & 60.8 \\
\hline Price reduction & 112 & 22.4 & 83.2 \\
\hline Out of interest & 10 & 2 & 85.2 \\
\hline Reward and fulfillment & 26 & 5.2 & 90.4 \\
\hline Giving out the prizes won & 11 & 2.2 & 92.6 \\
\hline Fun and prizes involved & 14 & 2.8 & 95.4 \\
\hline Free drinks and prizes & 15 & 3 & 98.4 \\
\hline Promo strategy & 8 & 1.6 & 100 \\
\hline Total & $\mathbf{5 0 0}$ & $\mathbf{1 0 0}$ & \\
\hline
\end{tabular}

Table 3: What motivated you to participate in the promotion?

\begin{tabular}{|l|c|c|c|}
\hline Response & Frequency & Percentage & $\begin{array}{c}\text { Cumulative } \\
\text { percentage }\end{array}$ \\
\hline Many, to win more prizes & 240 & 48 & 48 \\
\hline About 15, to win more prizes & 50 & 10 & 58 \\
\hline About 10, to win more prizes & 115 & 23 & 81 \\
\hline 5 bottles because it gives energy & 35 & 7 & 88 \\
\hline About 5, because it refreshes me & 26 & 5.2 & 93.2 \\
\hline 3 because of its nutrients & 24 & 4.8 & 98 \\
\hline No response & 10 & 2 & 100 \\
\hline Total & $\mathbf{5 0 0}$ & $\mathbf{1 0 0}$ & \\
\hline
\end{tabular}

Table 4: Showing level of persuasiveness of the promotional messages.

\begin{tabular}{|l|c|c|c|}
\hline Response & Frequency & Percentage & Cumulative Percentage \\
\hline Strongly agree & 128 & 25.6 & 25.6 \\
\hline Agree & 200 & 40 & 65.6 \\
\hline Neutral & 22 & 4.4 & 70 \\
\hline Strongly disagree & 83 & 16.6 & 86.6 \\
\hline Disagree & 67 & 13.4 & 100 \\
\hline Total & $\mathbf{5 0 0}$ & $\mathbf{1 0 0}$ & \\
\hline
\end{tabular}

Table 5: Opinion on patronage of Maltina and Malta Guinness brands.

\begin{tabular}{|l|c|c|c|}
\hline Response & Frequency & Percentage & $\begin{array}{c}\text { Cumulative } \\
\text { Percentage }\end{array}$ \\
\hline Because it cools my mind & 8 & 1.6 & 1.6 \\
\hline Low fat & 48 & 9.6 & 11.2 \\
\hline Taste & 239 & 47.8 & 59 \\
\hline For the fun of it & 32 & 6.4 & 65.4 \\
\hline Soothes me & 20 & 4 & 69.4 \\
\hline Nutritious & 30 & 6 & 75.4 \\
\hline Cost affordability & 32 & 6.4 & 75 \\
\hline The drink has been for a long time & 8 & 1.6 & 76.67 \\
\hline Product uniqueness & 18 & 3.6 & 78.34 \\
\hline Not after the promotion & 8 & 1.6 & 80.01 \\
\hline My favourite drink & 24 & 4.8 & 85.01 \\
\hline It is non-alcoholic & 18 & 3.6 & 86.68 \\
\hline No response & 15 & 3 & 100 \\
\hline Total & $\mathbf{5 0 0}$ & 100 & \\
\hline
\end{tabular}

Table 6: Show other reasons deduced for patronage of Maltina and Malta Guinness drinks.

$22(4.4 \%)$ is indifferent.

In Table 6, those who said they would patronize the brands regardless of sales promotion activities were asked the underlying reasons for their brand loyalty, 239 (47.8\%) opined that they love the brands because of the unique taste. Another 48 (9.6\%) of respondents stated that they like the brands because of the low fat content. 64 (12.8\%) of respondents gave their reasons for brand loyalty as cost effectiveness of the brands and the fun of drinking the brands.

Nevertheless when the field managers of Maltina and Malta 


\begin{tabular}{|l|c|c|c|}
\hline Response & Frequency & Percentage & Cumulative Percentage \\
\hline Great Extent & 95 & 19 & 19 \\
\hline Some Extent & 165 & 33 & 52 \\
\hline No Extent & 43 & 8.6 & 60.6 \\
\hline Little Extent & 197 & 39.4 & 100 \\
\hline Total & $\mathbf{5 0 0}$ & $\mathbf{1 0 0}$ & \\
\hline
\end{tabular}

Table 7: To what extent were you motivated by promotional messages?

Guinness were been interviewed, they itemized a number of benefits of sales promotions. According to them, the benefits are as follows:

- Increase in customer loyalty

- Increase in customer bounding

- TOMA (Top of Mind Awareness)

- Encourage consumers to call our brands by name, gets it at the right condition and enjoy the experience.

- Increase in volume

- Greater market share

- Better distribution

- Increase in availability of our brands.

In Table 7, responses indicate that majority of the respondents (52\%) who participated in sales promotions of Maltina and Malta Guinness were actually motivated by the promotional messages. However, these findings show that the $30 \%$ respondents in Table 5, who claimed to have patronized these brands due to sales promotion activities, were actually the target audience that Maltina and Malta Guinness needed in order to expand its market share.

\section{Analyses}

It was discovered that the overwhelming majority of the respondents were motivated by the prizes to be won during the sales promotion; thereby confirming the opinion that the promotional messages influence consumers' purchase decision. When the field managers were interviewed, they both itemized a number of benefits of sales promotions that acted as undermining factors for the use of sales promotions which was actually in line with what Shimp [10] mentioned. They also affirmed that the above mentioned strategies are often used to make sales promotion effective.

The responses from the respondents revealed that sales promotion actually increases market share of these products and consequently, increase the brand's competitive advantage. The attempts by these organizations in building competitive advantage through sales promotions were successful. Though respondents were motivated by promotional messages to participate in the sales promotions, they are also willing to stay true to their brand. This motivation or incentive is what Egan says sales promotion is all about-"Sales promotion is the offering of an incentive to make people act". The willingness on the part of the respondents to stay true to their brands has negated the opinion of Corfman and Ragubir cited in Kazim and Batra [12] that "offering sales promotion programmes to support products penetration into the market on constant basis is more likely to lower a brand evaluation of value.

Mixed strategies were used by these two manufacturers of malt.

Dominant strategy: Collusion on Price. It was gathered during the interview that the manufacturers agreed not to go beyond \#100 per bottle. They also agreed on when to hold the sales promotions and where. They believe in first mover. In other words, each of them goes to new ground and later holds sales promotion to create awareness and still build brand loyalty.

Weak strategy: They choose the weak strategy in order to reduce the market share of their competitor. Even though the theory predicts that they should hold sales promotions separately which is the dominant strategy, the desire to reduce the market share of the competitor makes it appealing to run the sales promotions at the same time and deprive their competitor of the possible gains. For instance, the field manager affirmed that Malta Guinness got to Benin before Maltina. However, Malta Guinness first held its sales promotions. When Maltina organized its sales promotion introduced another kinds of sales promotions different from what Malta Guinness has used. It also improved on Malta Guinness' kind of sales promotions. Malta Guinness did bar sales promotions where the barman produces the number of corks sold to get gifts ranging from extra crates of drinks to branded shirts, T shirts, biros, and umbrella. Maltina reduced the number of corks of drinks sold to get the gifts. Quality of the shirts and $\mathrm{T}$ shirts that were given out was far better than Malta Guinness. The barmen later preferred to sell Maltina to Malta Guinness though not all of them were won over. According to the field manager of Maltina, the customers that were won over at least reduced the market share of Malta Guinness and it is gain to them as Maltina is sole seller of malt in some other places like Makurdi.

It can therefore be inferred from this analysis that the remaining customers that could not be won over by Maltina are those that are loyal to Malta Guinness.

\section{Conclusion}

Based on the above, it can be inferred that sales promotion is an effective strategy used in promotion of the two malt products-Maltina and Malta Guinness. By default, it can also be inferred that since it worked in the case of the two malt products, in Nigeria, it will work elsewhere in the world and in the marketing and sales of any other product(s) and/or service(s).

\section{References}

1. Den-Brae Q (2005) Strategic business management. Houston, Texas: Lizman and Brown.

2. Kenthra R and Ellis M (2007) Marketing management, New Jersey: Enny Bic Prints.

3. Gidred G (2007) Avoiding marketing myopia in $21^{\text {st }}$ century Journal of Consumer Research.

4. Abayomi S (2003) Introduction to marketing Lagos: Power Tower.

5. Zyman S (2001) The end of advertising as we know it. New Jersey.

6. Kotler $P$ (2001) Marketing management. New Jersey: Prentice-Hall.

7. Kotler P, Keller K (2009) Marketing. New Jersey: Prentice-Hall.

8. Obe O (2009) Celebration of Irrationality in the Name of Marketing. Lagos: Mix Publishers.

9. Egan J (2007) Marketing communications London: Thomson Leaning

10. Shimps F (2007) Advertising and promotion: Integrated approach New York: New Trends.

11. Dozie E (2009) Nigerian market dynamics: Matters Arising. Journal of Brand Management.

12. Kazim A, Batra W (2007) Winning with sales promotion Mumbai: Orange Valley Inc., University of Michigan.

13. Fill C (2009) Marketing Communications: Interactivity, communities and content Essex: Pearson Education. 